\title{
Covid-19 Pandemic: A Curse to World
}

\author{
Rohit R Doke*1, Ajay A Bhagwat ${ }^{2}$, Rahul P Lokhande ${ }^{2}$
}

\begin{abstract}
The evolving coronavirus disease (COVID-19) spread across the world, affecting more than 200 countries and territories. The genomic analysis proposed that the COVID-19 virus first observed in bats and later spread to humans through unidentified intermediate hosts in the Wuhan Seafood Market, China, in December of 2019. COVID-19 belongs to the family of Beta coronavirus and also refers to severe acute respiratory syndrome coronavirus 2(SARS-CoV2) due to its genetic similarities with severe acute respiratory syndrome coronavirus (SARS-CoV- pandemic observed in 2003).

At present no any promising treatment strategies or vaccine is available. Hence many researchers and physicians are studying existing agents for its use against COVID-19 infections. Although it provides only symptomatic relief, it helps to halt infection.

The intention of this review article is to provide a brief summary of the origin, basic structure, pathogenicity, potent available therapeutic strategies against COVID-19 infection.'
\end{abstract}

Keywords: COVID-19, Pathogenicity, SARS-CoV2, Structure, Treatment strategies

Asian Pac. J. Health Sci., (2020); DOI: 10.21276/apjhs.2020.7.2.10

\section{INTRODUCTION}

The capricious outbreak coronavirus disease 2019 was first recognized in patients with severe respiratory Disease in Wuhan, Hubei, China. Earlier research has been called this outbreak as pneumonia of unknown etiology. ${ }^{[1]}$ The causative agent was identified by testing throat swab of such infected patients led by the Chinese Centre for Disease Control and Prevention (CCDC) on Jan 7, 2020, which later on named by World Health Organization (WHO) and International Committee on the taxonomy of Virus (ICTV) as a Severe Acute Respiratory Syndrome Coronavirus 2(SARS-CoV 2) and disease as a COVID-19 due to its crown-like structure. ${ }^{[2,3]}$ The name of SARS-CoV 2 due it is genetically and structurally resemblances with severe acute respiratory syndrome coronavirus ${ }^{[4]}$ From the last two decades there are three emerging viruses has been reported form the same family of coronavirus that are severe acute respiratory syndrome (SARS-CoV), middle east. respiratory syndrome (MERS) and recently its SARS CoV2. ${ }^{[11]}$ The first outbreak of SARS-CoVwere came in Guangdong province, Southern China, and neighboring countries in $2003^{[5]}$ leads to 813 deaths among 8437 reported cases worldwide. ${ }^{[6]}$ Then after nine years, the respiratory syndrome was reported in the middle east has been called MERS, which adds burdens of a total of 2519 laboratory-confirmed cases, including 866 associated deaths (case-fatality rate: $34.3 \%$ ) were reported globally. ${ }^{[7,8]}$ and now its SARS-CoV2 affecting the lives of millions. Even though most of the countries declared lockdown and national emergencies, the infection and severity of pandemic is increasing day by day as there is no promising treatment has been found till the date. Since its discovery, more than 3435894 cases have been infected, including nearly 239604 deaths. ${ }^{[9,10]}$

Coronavirus disease (COVID-19) pandemic is continuously spreading across the world very promptly. The mild conditions like the common cold and severe circumstances such as severe acute respiratory syndrome coronavirus (SARS-CoV)and Middle East respiratory syndrome coronavirus (MERS-CoV) are the leading problems of coronavirus infection. ${ }^{[11]}$ The worrisome features of COVID-19 are its capacity to spread rapidly, and its tendency to reason severe disease in geriatric populations and patients with existing health disorders. The virus is contagious and transferred from one individual to next through sneezing and coughing or contact with the secretion of infected persons. COVID-19 disease is
Samarth Rural Educational Institutes Samarth College of Pharmacy, Belhe 412410, Pune, India

Corresponding Author: Rohit R Doke, Samarth Rural Educational Institutes Samarth College of Pharmacy, Belhe 412410, Pune, India, Email: rohitdoke2853@gmail.com

How to cite this article: Doke RR, Bhagwat AA, Lokhande RP. Covid-19 Pandemic: A Curse to World. Asian Pac. J. Health Sci., 2020; 7(2):38-41

Source of support: Nil

Conflict of interest: None

Received: 14/04/2020 Revised: 07/05/2020 Accepted: 13/05/2020

more severe in the elderly and persons with other chronic diseases such as chronic respiratory disease, diabetes, cardiovascular disease, hypertension, and renal injury). The COVID-19 is characterized by symptoms such as dry cough fatigue, fever, and, as well as sputum production, headache, etc. ${ }^{[12-14]}$

At present, no hopeful antiviral regimens or vaccines are existing for COVID-19. Some guidelines are issued by the health authority of each country and also by the WHO to treat COVID-19 pandemic. However, the existing treatment protocols are mainly based on providing symptomatic relief and upregulation of respiratory functions.

\section{Origin, Basic Structure, and Pathogenesis}

Coronaviruses (CoVs) are a large group of viruses common among many animals, including Human. They can cause respiratory illnesses in humans and gastrointestinal illnesses in animals. Some basic information ${ }^{[15]}$ regarding to CoVs are given in Table 1.

Table 1: Origin, basic structure of CoVs

\begin{tabular}{l}
\hline Family-coronaviridae \\
Subfamily-Nidovirales \\
Order-Nidovirales \\
Subgroups-alpha (a), beta $(\beta)$, gamma $(\gamma)$ and delta $(\delta)$ coronavirus. \\
Size-65-125nm in diameter \\
Contains Single-stranded RNA, \\
crown-like spikes on the outer surface of the virus
\end{tabular}

(02020 The Author(s). This is an open access article distributed under the terms of the Creative Commons Attribution License (http:// creativecommons.org/licenses/ by/4.0/), which permits unrestricted use, distribution, and reproduction in any medium, provided the original work is properly cited. 
Human have long been infected by coronavirus since from 2003 outbrek of SARS followed by MERS (2012) and COVID-19. All three diseases are contagious, which can be transmitted from person to person during coughing, sneezing by the inhalation or ingestion of viral droplets, and also when a person comes in contact with an infected source. ${ }^{[16]}$ The coronavirus genome is consists of 30000 nucleotides, which encodes for several proteins such as nucleocapsid (N) protein, membrane (M) protein, Spike (S) protein, and Envelop (E) protein and several non-structural proteins (nsp) as shown in Figure 2. The genetic material is enclosed within the enveloped protein of lipid bilayer. The SARS-CoV 2 is a singlestranded RNA virus that is positioned within capsid protein and surrounded by the nucleocapsid protein or N-protein. The singlestranded RNA material further responsible for the production of genomic and subgenomic material by the accomplishment of processes like replication and transcription(mediated by the $\mathrm{N}$-terminal of nucleocapsid protein/N-protein) and also allows the virus to steal human cells and convert them into virus factories. The membrane/ $\mathrm{M}$ - protein is mostly found at the virus surface and maintained the intact structure of the virus. The binding of viral spike protein with host cell surface receptors is governed by $M$-protein, which further responsible for the entry of the virus in a host cell. ${ }^{[20]}$ The major functions of membrane permeability and virus-host cell interaction are carried out by the E-protein. ${ }^{[21]}$ [Figure 1].

\section{Pathogenesis}

Basically, the SARS-CoV2 has a characteristic spike protein, which plays a crucial role in binding of virus with host cell surface receptors. It has been reported that the spike proteins contain a receptor- binding domain (RBD). The glutamine residue of this domain forms a virus-host receptor complex by binding with lysine residue of the human angiotensin-converting enzyme 2 (ACE2) receptors. Subsequently, receptor binding leads to the fusion of viral and host cell membranes and further releases single-stranded genomic RNA into the cytoplasm of the host cell. Then this single-stranded RNAundergoes translation and replication to produce polyproteins (pp1a and pp1ab), which subsequently cleave into 15-16 nsps. Following the translation and replication, negative-sense copies of both genomic and subgenomic RNAs are synthesized, which serve as templates for the synthesis of positive-sense genomic RNA and subgenomic mRNAs. The subgenomic mRNAs act as a template for the production of the various structural and several other proteins. Then the nucleocapsid is formed by incorporation of viral genomic RNA into N protein, which further interacts with the endoplasmic reticulum (ER) and transfers to the endoplasmic reticulum-Golgi intermediate compartment (ERGIC) where the other M, S, E protein is being developed. Finally, new virions are covered by the smooth-walled vesicles and then transported across the membrane of infected cell by the membrane transport mechanism i.e. exocytosis. However due to the burden of viral RNA and other Structural proteins in the ER and ERGIC, ultimately cell death occurs [Figure 2]. ${ }^{[24]}$

SARS-CoV-2with the help of S protein virus binds to the cellular receptor ACE2. After receptor binding, the viral RNAreleases into cytoplasm, followed by the replication and translation to form new genomic, sub-genomic viral material, other structural and nonstructural proteins. Viral proteins and genome RNA are afterward collected into virions in the ER and ERGIC and then transported via vesicles and released out of the cell via exocytosis mechanism.

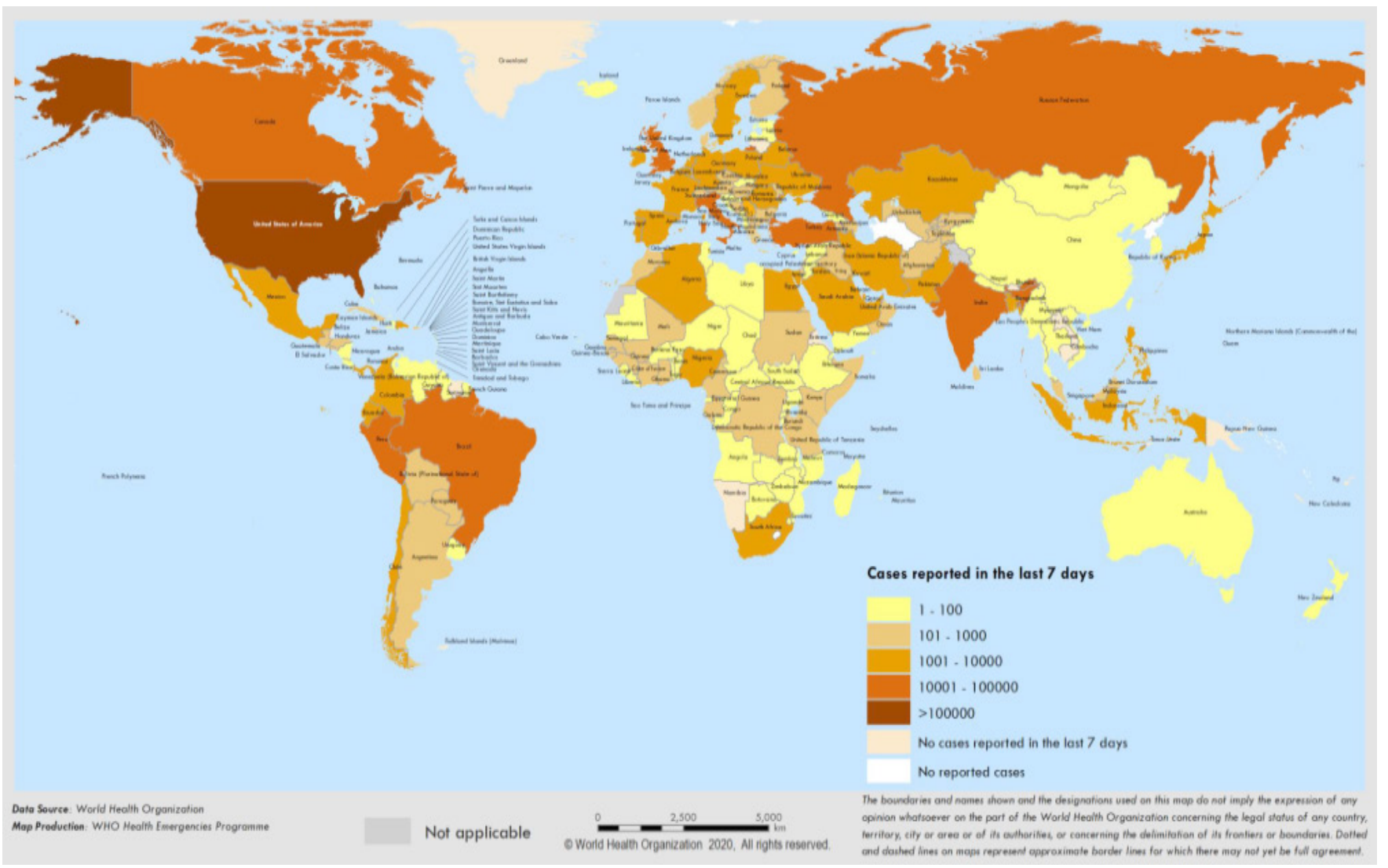

Figure 1: Number of confirmed COVID-19 cases reported in the last seven days by country, territory or area, Apr 28 to May $4 * *$ Source: https://www.who.int/docs/default-source/coronaviruse/situation-reports/20200504-covid-19-sitrep-105.pdf?sfvrsn=4cdda8af_2 
Table 2: List of potential drug candidates used against SARS-CoV-2 Infection

\begin{tabular}{|c|c|c|}
\hline Drugs & Mechanism & Reference \\
\hline Chloroquine and hydroxychloroquine & $\begin{array}{l}\text { Inhibition of Heme polymerase, inhibit } \mathrm{P}^{\mathrm{H}} \text {-dependent steps of viral replication } \\
\text { and maintain normal body temperature }\end{array}$ & [26] \\
\hline Lopinavir /Ritonavir & $\begin{array}{l}\text { HinderingSARS-CoV- } 2 \text { protease for } \\
\text { proteins cleavage, inhibit protein synthesis and thus virus replication }\end{array}$ & {$[27,28]$} \\
\hline Remdesivir & Inhibit RNA Polymerase and interfere with viral RNA replication & [29] \\
\hline Ivermectin & Inhibits In-vitro replication of SARS-CoV-2 & {$[30]$} \\
\hline Darunavir & Inhibits In-vitro viral RNA replication of SARS-CoV-2 & [31] \\
\hline $\begin{array}{l}\text { Cepharanthie and } \\
\text { Selamectin, }\end{array}$ & $\begin{array}{l}\text { Control cytopathogenic effect of } \\
\text { SARS-CoV-2, and decrease } \\
\text { the viral load }\end{array}$ & {$[32]$} \\
\hline CamostatMesylate & inhibitor Interfering with viral entry & [33] \\
\hline Azithromycin & Reduce viral load & {$[34]$} \\
\hline Nitric oxide & Rescue refractory hypoxia( Respiratory distress symptomatic treatment) & [35] \\
\hline
\end{tabular}

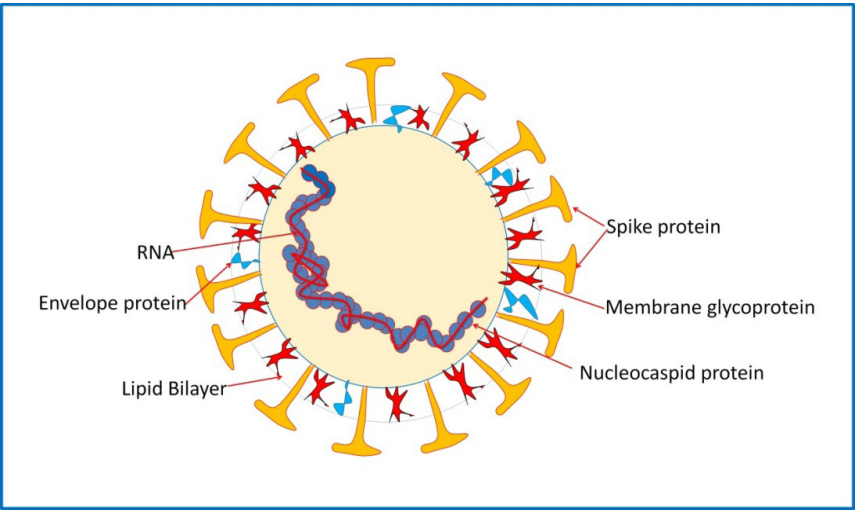

Figure 2: Basic structure of SARS-CoV-2 virus

ACE2- angiotensin-converting enzyme 2; ER- endoplasmic reticulum; ERGIC, ER-Golgi intermediate compartments.

\section{Treatment}

Till the date, no any promising and curative treatment available against SARS-CoV2 infection. As the outbreak of the covid19 pandemic is increasing rapidly, leading to more deaths throughout the world. Whichever treatment protocols using currently only provide symptomatic relief and also the potential curative changes from person to person. So it takes more attention to develop novel therapeutic management against COVID19, which can control the progression of infection and thus subsequently halts symptoms.

There is multiple drug candidates are currently used and further investigated, currently using treatment protocols are based on following principals i) Inhibition of SARS- Cov 2 fusion/entry ii) disruption of SARS-CoV 2 replication iii)suppression of excessive inflammatory response iv)convalescent plasma treatment v) Vaccines. ${ }^{[25]}$ The potential dug candidates currently available to treat COVID19 are listed below.[Table 2]

The use of convalescent plasma transfusion could be of great value in the current pandemic of corona disease pandemic. The immediate use of convalescent plasma provides prompt availability of a promising treatment while specific vaccines and treatment are evaluated and brought to scale. Convalescent plasma from donors who have recovered from COVID19 may be most promising when used as prophylaxis or when administered shortly after symptoms onset within 14 days. ${ }^{[35]}$ The scientist and physicians across the globe continuously working hard to find vaccines against SARSCoV-2.

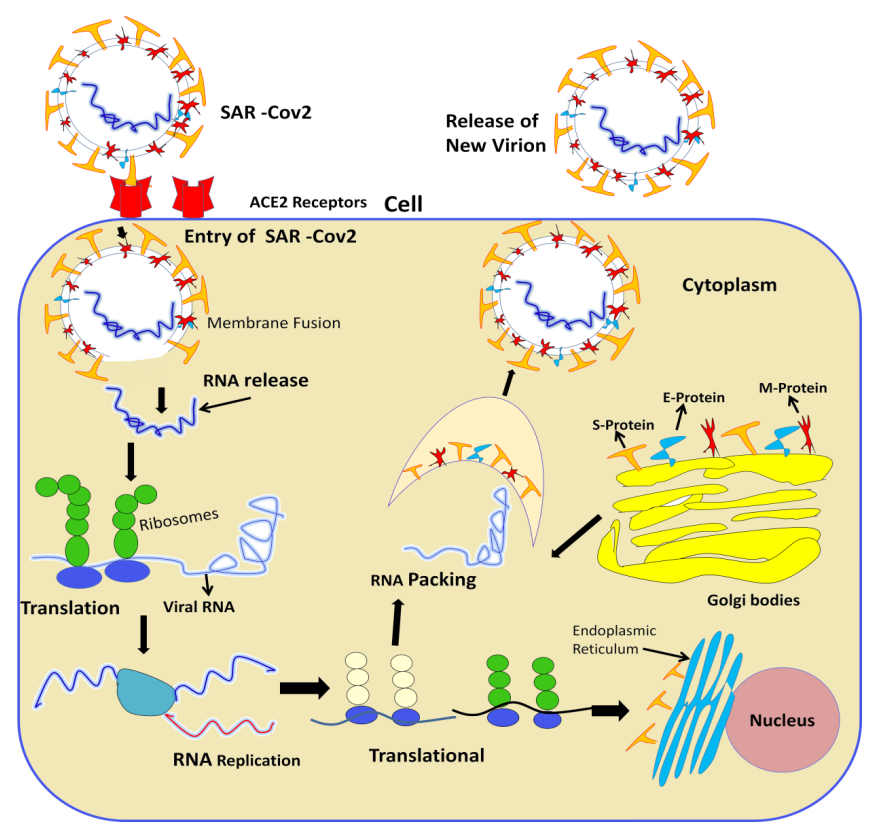

Figure 3: The life cycle of SARS-CoV-2 in host cells

\section{Conclusion}

The COVID-19 pandemic becomes a global threat to affect public health systems. The severity of pandemic leading to an increasing number of cases and deaths day by day. Although WHO other health authorities of world and every countries prescribed several guidelines to deal with this pandemic and Regardless of knowing infectious cycleSARS-CoV-2, there are no promising approaches for COVID-19 patients' treatment. For the last four months, many scientists and physicians' working day and night to find novel curative treatments and vaccine against SARS-CoV- 2 infection. Most of these findings are based on antiviral activities of existing drug candidates. So from here now only time will tell us which one of these drugs is going to work?

\section{References}

1. Bogoch II, Watts A, Thomas-Bachli A, Huber C, Kraemer MU, Khan K. Pneumonia of Unknown Etiology in Wuhan, China: Potential for International Spread Via Commercial Air Travel. Journal of Travel Medicine. 2020 Jan 14.

2. Chakraborty C, Sharma AR, Sharma G, Bhattacharya M, Lee SS. SARSCoV-2 causing pneumonia-associated respiratory disorder (COVID-19): 
diagnostic and proposed therapeutic options. European Review for Medical and Pharmacological Sciences. 2020 Apr 1;24(7):4016-26.

3. Naming the coronavirus disease (COVID-19) and the virus that causes it https://www.who.int/emergencies/diseases/novel-coronavirus-2019/ technical-guidance/naming-the-coronavirus-disease-(covid-2019)and-the-virus-that-causes-it

4. of the International CS. The species Severe acute respiratory syndromerelated coronavirus: classifying 2019-nCoV and naming it SARS-CoV-2. Nature Microbiology. 2020 Mar 2:1.

5. Peng GW, He JF, Lin JY, Zhou DH, Yu DW, Liang WJ, Li LH, Guo RN, Luo $\mathrm{HM}, \mathrm{Xu} \mathrm{RH}$.

6. Epidemiological study on severe acute respiratory syndrome in Guangdong province. Zhonghualiuxingbingxuezazhi= Zhonghualiuxingbingxuezazhi. 2003 May;24(5):350-2.

7. Zhong NS, Zheng BJ, Li YM, Poon LL, Xie ZH, Chan KH, Li PH, Tan SY, Chang Q, Xie JP, Liu XQ. Epidemiology and cause of severe acute respiratory syndrome (SARS) in Guangdong, People's Republic of China, in February, 2003. The Lancet. 2003 Oct 25;362(9393):1353-8.

8. Zaki AM, Van Boheemen S, Bestebroer TM, Osterhaus AD, Fouchier RA. Isolation of a novel coronavirus from a man with pneumonia in Saudi Arabia. New England Journal of Medicine. 2012 Nov 8;367(19):1814-20.

9. WHO ,Middle East Respiratory Syndrome, MERS situation update, January 2020,http://www.emro.who.int/health-topics/mers-cov/ mers-outbreaks.html

10. Coronavirus disease (COVID-19) Situation Report- 106 Data as received by WHO from national authorities by 10:00 CEST, May 52020 https://www.who.int/docs/default-source/coronaviruse/situationreports/20200504-covid-19-sitrep-105.pdf?sfvrsn=4cdda8af_2

11. Cascella M, Rajnik M, Cuomo A, Dulebohn SC, Di Napoli R. Features, evaluation and treatment coronavirus (COVID-19). InStatpearls [internet] 2020 Mar 8. StatPearls Publishing.

12. Guarner J. Three emerging coronaviruses in two decades: the story of SARS, MERS, and now COVID-19.

13. Chen N, Zhou M, Dong X, Qu J, Gong F, Han Y, Qiu Y, Wang J, Liu Y, Wei Y, Yu T. Epidemiological and clinical characteristics of 99 cases of 2019 novel coronavirus pneumonia in Wuhan, China: a descriptive study. The Lancet. 2020 Feb 15;395(10223):507-13

14. Guo YR, Cao QD, Hong ZS, Tan YY, Chen SD, Jin HJ, Tan KS, Wang DY, Yan Y. The origin, transmission and clinical therapies on coronavirus disease 2019 (COVID-19) outbreak-an update on the status. Military Medical Research. 2020 Dec;7(1):1-0.

15. Sohrabi C, Alsafi Z, O'Neill N, Khan M, Kerwan A, Al-Jabir A, losifidis C, Agha R. World Health Organization declares global emergency: A review of the 2019 novel coronavirus (COVID-19). International Journal of Surgery. 2020;3(2):23

16. Andersen KG, Rambaut A, Lipkin WI, Holmes EC, Garry RF. The proximal origin of SARS-CoV-2. Nature medicine. 2020 Apr;26(4):450-2.

17. 16.Bi Q, Wu Y, Mei S, Ye C, Zou X, Zhang Z, Liu X, Wei L, Truelove SA, Zhang T, Gao W. Epidemiology and Transmission of COVID-19 in Shenzhen China: Analysis of 391 cases and 1,286 of their close contacts. MedRxiv. 2020 Jan 1.

18. Hoffmann M, Kleine-Weber H, Schroeder S, Krüger N, Herrler T, Erichsen S, Schiergens TS, Herrler G, Wu NH, Nitsche A, Müller MA. SARS-CoV-2 cell entry depends on ACE2 and TMPRSS2 and is blocked by a clinically proven protease inhibitor. Cell. 2020;5(9):90

19. Sarma, P., Sekhar, N., Prajapat, M., Avti, P., Kaur, H., Kumar, S., Singh, S.,Kumar, H., Prakash, A., Dhibar, D. P., Medhi, B. (2020). In-silico homologyassisted identification of inhibitor of RNA binding against
2019-nCoV N-protein (N terminal domain). Journal of Biomolecular Structure\& Dynamics. https://doi.org/10.1080/07391102.2020. 1753580

20. D Walls AC, Park YJ, Tortorici MA, Wall A, McGuire AT, Veesler D. Structure, function, and antigenicity of the SARS-CoV-2 spike glycoprotein. Cell. 2020 Mar 9.

21. Kirchdoerfer RN, Cottrell CA, Wang N, Pallesen J, Yassine HM, Turner $\mathrm{HL}$, Corbett KS, Graham BS, McLellan JS, Ward AB. Pre-fusion structure of a human coronavirus spike protein. Nature. 2016 Mar;531(7592):118121.

22. Gupta MK, Vemula S, Donde R, Gouda G, Behera L, Vadde R. In-silico approaches to detect inhibitors of the human severe acute respiratory syndrome coronavirus envelope protein ion channel. Journal of Biomolecular Structure and Dynamics. 2020 Apr 2 (just-accepted):1-7.

23. Li F, Li W, Farzan M, Harrison SC. Structure of SARS coronavirus spike receptor-binding domain complexed with receptor. Science. 2005 Sep 16;309(5742):1864-8

24. Chen Y, Guo Y, Pan Y, Zhao ZJ. Structure analysis of the receptor binding of 2019-nCoV. Biochemical and biophysical research communications. 2020 Feb 17.

25. Masters, P. S. (2006). The molecular biology of coronaviruses. Advances in Virus Research, 65(06), 193-292. https://doi.org/10.1016/S00653527(06)66005-3

26. Li h, Zhou Y, Zhang M, Wang H, Zhao Q, liu J. Updated approaches against SARS-CoV-2. Antimicroial agent and chemotherapy. 2020 Mar 23.

27. Gao J, Hu S. update on use of chloroquine/ hydroxychloroquine to treat coronavirus disease 2019 (COVID19) BiosciemceTreands 2020

28. Moro S, Bolcato G, Bissaro M, Pavan M, Sturlese M. targeting the coronavirus SARS-CoV-2: Computational Isights Into The Mechanism of Action of the Protease Inhibitors Lopinavir, Ritonavir and Nelfinavir

29. .Lim, J.; Jeon, S.; Shin, H.-Y.; Kim, M.J.; Seong, YM; Lee,W.J.; Choe, K.-W.; Kang, Y.M.; Lee, B.; Park, S.-J. Caseof the index patient who caused tertiary transmission of coronavirus disease 2019 in Korea: The applicationoflopinavir/ritonavir for the treatment of COVID-19 pneumonia monitored by quantitative RT-PCR. J. Korean Med Sci. 2020, 35, e79.

30. Gordon CJ, Tchesnokov EP, Feng JY, Porter DP, Götte M. The antiviral compound remdesivir potently inhibits RNA-dependent RNA polymerase from Middle East respiratory syndrome coronavirus. Journal of Biological Chemistry. 2020 Apr 10;295(15):4773-9.

31. Caly L, Druce JD, Catton MG, Jans DA, Wagstaff KM. The FDA-approved Drug Ivermectin inhibits the replication of SARS-CoV-2 in vitro. Antiviral research. 2020 Apr 3:104787.

32. Dong L, Hu S, Gao J. Discovering drugs to treat coronavirus disease 2019 (COVID-19). Drug discoveries \& therapeutics. 2020 Feb 29;14(1):58-60.

33. Fan, H.-H.; Wang, L.-Q.; Liu, W.-L.; An, X.-P.; Liu, Z.-D.; He, X.-Q.; Song, L.-H.; Tong, Y.-G. Repurposing of clinically approved drugs for treatment of coronavirus disease 2019 in a 2019-novel coronavirus (2019-nCoV) related coronavirus model. Chin. Med. J. 2020.

34. Alanagreh LA, Alzoughool F, Atoum M. The Human Coronavirus Disease COVID-19: Its Origin, Characteristics, and Insights into Potential Drugs and Its Mechanisms. Pathogens. 2020 May;9(5):331.

35. EvangelinMP., Krishna BG., Raju SG., Radhika G. Vamsi GK, COVID-19: Investigational Drugs. Journal of medical Biomedical and Applied Sciences.2020 Apr 1;8(4):358-60

36. Brown BL, Mccullough J. Treatment For Emerging Viruses:Convalescent Plasma And Apheresis Science, 2020 Apr 20: 102790. 